\title{
Selective cytotoxic effect of Plantago lanceolata L. against breast cancer cells
}

Khulood M. Alsaraf ${ }^{1}$, Maeda H. Mohammad², Ahmed Majeed Al-Shammari² ${ }^{*}$ (D) and Ibrahim S. Abbas ${ }^{3}$

\begin{abstract}
Background: Plantago lanceolata L. is used in Iraqi folklore medicine to treat injuries, and its extract is prescribed by some herbalists for cancer patients. This research aimed to evaluate the effect of $P$. lanceolata leaf extract on breast cancer cell lines in vitro and to identify its active compounds. Crystal violet viability assay was used to determine the cytotoxicity of methanolic P. lanceolata leaf extract against various breast cancer cell lines. MCF7, AMJ13, MDAMB, and CAL51 human breast cancer cells were treated with different concentrations of the extract for $72 \mathrm{~h}$. The morphology of the treated cells was examined under a phase-contrast inverted microscope. The clonogenic ability was assessed through a clonogenic assay. High-performance liquid chromatography (HPLC) analysis was performed to measure the concentrations of phenols and flavonoids in the extract.

Results: The methanolic $P$. lanceolata leaf extract significantly inhibited the proliferation of triple-negative CAL51 cells but showed minor effect on the other breast cancer cells. In addition, at high doses, it induced cytopathic morphological changes. The clonogenic assay showed low colony formation in the exposed cells, especially CAL51 cells. Furthermore, HPLC study revealed that the methanolic extract contained important flavonoid glycosides, especially rutin, myricetin quercetin, and kaempferol.

Conclusions: P. lanceolata leaf extract selectively inhibited the proliferation of CAL51 triple-negative breast cancer cells and showed minor effect on the other breast cancer cells types studied. Thus, this study showed P. lanceolata as a possible natural source of selective anti-triple-negative breast cancer drugs.
\end{abstract}

Keywords: Cytotoxicity, HPLC analysis, Flavonoids, Iraq, Clonogenic assay

\section{Background}

Cancer is a complex disease that is difficult to be treated [1]. Cancer incidence has increased globally, and especially in Iraq, it has increased owing to several factors related to environmental pollution associated with several years of conflicts [2]. Breast malignant tumors are the second leading cause of mortality among Iraqi women [3]. However, conventional cancer treatments, such as chemotherapy, radiation, targeted therapy, and immunotherapy, have harmful side effects. Therefore, herbal medicine has been considered a useful alternative to the currently existing therapies [4]. Herbal medicine is widely used for treating several types of cancers because it has fewer side effects than conventional cancer therapeutics [5].

\footnotetext{
* Correspondence: ahmed.alshammari@iccmgr.org

${ }^{2}$ Experimental Therapy Department, Iraqi Center for Cancer and Medical

Genetic Research, Mustansiriyah University, Baghdad, Iraq

Full list of author information is available at the end of the article
}

In Iraq, ribwort (Plantago lanceolata L.) is used for injury treatment [6], and its extract is prescribed by some herbalists to cancer patients. This plant is one of the medicinally important plants officially registered in the British pharmacopeia. Ribwort, also known as narrow leaf plantain, is rich in phytochemical compounds [7]. Ribwort is originally native to Europe and temperate areas of Asia, but it has been cultivated in all temperate regions of the world [8]. P. lanceolata leaves are erect, straight, and sheltered with soft minute hairs; they reach up to approximately $17 \mathrm{in.}$ long and taper at the base into a slender petiole. The flowers are condensed spikes on the top of the stalks; the flowers consist of a small corolla, four sepals, and two stamens [9]. This plant contains major secondary metabolites including mucilages (6\%), tannins (more than 5\%) [10], and phenyl propanoids [11], with verbascoside as a major constituent [12], as well as iridoid glycosides [13], mainly aucubin and cutalpol. It also contains minor secondary metabolites, such as flavonoids [14], coumarins, volatile compounds [15], and saponin. Global studies 
showed that ribwort seeds have external uses for treating skin inflammation and healing wounds [16]. It is found that crude extracts of Plantago leaves have anti-proliferative effect on MCF7 breast cancer cell line [17] and against prostate cancer cell lines [18]. However, the antitumor effect of this plant has not been much studied. Thus, this study aimed to identify the active compounds of $P$. lanceolata leaf extract and evaluate its antitumor effect on cancer cell lines in vitro.

\section{Methods}

\section{Collection of plant samples}

P. lanceolata leaves were collected from a Usefia region south Baghdad at middle of Iraq. The plants were confirmed to be uninfected and healthy, and authenticated by the National Herbarium of Iraq who undertook the formal identification of the plant material used in our study, and a specimen of this material has been deposited in a National Herbarium of Iraq under the number (56432). The leaves were washed by clean tap water and distilled water to eliminate dust and other foreign particles, air-dried at room temperature, ground in a blender, and then weighed.

\section{Plant extraction}

Plant leaves $(100 \mathrm{~g})$ were ground into fine powder using a stainless-steel grinder and then extracted in $70 \%$ ethanol $(200 \mathrm{ml})$ overnight. The fraction extracted by ethanol was isolated by using a muslin cloth and sterile filtered through a Whatman filter (No.02) paper. The filtered extract was then concentrated in a rotary evaporator.

\section{Analysis of phenol and flavonoid content in P. lanceolata leaf extract}

Detection of flavonoid was performed using a highperformance liquid chromatography (HPLC) system from Shimadzu, Japan, following previously described methods [19] at the Department of Chemistry, Ministry of Science and Technology. The column used was Shimpack C-18 (particle size of $3 \mu \mathrm{m} ; 50 \times 4.6 \mathrm{~mm}$ 1.D). The mobile phase was $0.1 \%$ phosphoric acid-acetonitrile $(52: 24$, v $\backslash \mathrm{v})$. UV detection was set at $285 \mathrm{~nm}$. The flow rate was $1.5 \mathrm{ml} / \mathrm{min}$, whereas the temperature was $25^{\circ} \mathrm{C}$. The concentration of each component was measured quantitatively by comparing the detected peak area of the samples with that of a standard according to the following equation:

Sample concentration $=\frac{\text { area of the sample }}{\text { area of the Standard }} \times$ standard concentration $\times$ dilution factor

\section{Maintenance of cell cultures}

The human breast cancer cell lines AMJ13 [20], MCF7, MDAMB, and CAL51, as well as mouse embryo fibroblasts (MEF) were supplied by Cell Bank Unit. AMJ13 cells were cultured in RPMI-1640 medium (USbiological, USA) supplemented with $10 \%$ fetal bovine serum (FBS) (Capricorn
Scientific, Germany), 100 units/mL penicillin, and $100 \mu \mathrm{g} /$ $\mathrm{mL}$ streptomycin. MCF7, MDAB, and CAL51 cells were cultured in Minimum Essential medium (MEM) (USbiological) supplemented with 10\% FBS (Capricorn- Scientific, Germany), $100 \mu \mathrm{g} / \mathrm{mL}$ streptomycin, and 100 units $/ \mathrm{mL}$ penicillin. The cells were incubated at $37^{\circ} \mathrm{C}$ in a humidified environment and $5 \% \mathrm{CO}_{2}$.

\section{Cytotoxicity assays}

Crystal violet cell viability assay was employed to measure the cytotoxic effect of the plant extract. Human breast cancer cell lines (MDAMB, AMJ13, MCF7, and CAL51 cells) and normal mouse embryonic cells (MEF) were seeded at a density of 7000 cells/well in 96-well plates (Santa Cruz Biotechnology, USA). After 24h of incubation or after a confluent monolayer was formed, the cells were treated with $P$. lanceolata leaf extract at 2-fold dilutions (4000, 2000, 1000, 500, 250, 125, 62.5, $31.25 \mu \mathrm{g} / \mathrm{ml}$ to $15 \mu \mathrm{g} / \mathrm{ml}$ ) in culture media. The assay was performed in triplicate. Cell viability was determined after $72 \mathrm{~h}$ of treatment by cell staining with $50 \mu \mathrm{l}$ of crystal violet (Sigma Aldrich, USA) followed by incubation at $37{ }^{\circ} \mathrm{C}$ for $2 \mathrm{~h}$. The stain was aspirated, and PBS was used to wash the wells. A microplate reader (Biochrom, UK) was used to measure the absorbance at $492 \mathrm{~nm}$. Results of the assay were shown as percentage of proliferation relative to control cells [21].

\section{Morphology and quantitative image analyses}

The treated and untreated cells were photographed at four haphazardly selected cultured fields using an inverted light microscope at $\times 200$ magnification (Leica Microsystems, Germany) and digital color camera (Leica-microsystems, Germany). The images were examined using the ImageJ software (http://rsb.info.nih.gov/ij/). For statistical analysis, quantitative measurement of each picture was performed in triplicate. Percentage (\%) of cells stained by crystal violet were calculated [22].

\section{Clonogenic assay}

The cells were seeded at a density of $5 \times 10^{5}$ cells $/ \mathrm{mL}$ in 6-well tissue culture plates and incubated until confluency. Next, the cells were exposed to P. lanceolata leaf extract at different concentrations. The cells were then stained with crystal violet stain and examined under an inverted microscope [23].

\section{Statistical analysis}

The data are presented as means \pm standard error of the mean. One-way analysis of variance was used for data comparison between treatment groups. Differences in data were considered statistically significant at $P<0.05$. For this analysis, we used the GraphPad Prism 6 software (GraphPad Software, Inc. San Diego, California). 
Table 1 Bioactive compounds of $P$. lanceolata leaf extract, identified by HPLC

\begin{tabular}{|c|c|c|c|c|c|c|c|c|c|}
\hline Seq & Standard & $\begin{array}{l}\text { Retention time } \\
\text { (minutes) }\end{array}$ & Area & $\begin{array}{l}\text { Concentration } \\
\mu \mathrm{g} / \mathrm{ml}\end{array}$ & Seq & Sample & $\begin{array}{l}\text { Retention time } \\
\text { (minutes) }\end{array}$ & Area & $\begin{array}{l}\text { Concentration } \\
\mu \mathrm{g} / \mathrm{ml}\end{array}$ \\
\hline 1 & $\begin{array}{l}\text { Protocatecuic } \\
\text { acid }\end{array}$ & 2.198 & 576685 & 12.10 & 1 & $\begin{array}{l}\text { Protoctecuic } \\
\text { acid }\end{array}$ & 2.152 & 65876 & 3.88 \\
\hline 2 & Cafeic acid & 2.957 & 572594 & 12.02 & 2 & Cafeic acid & 2.898 & 43719 & 5.23 \\
\hline 3 & Ferulic acid & 4.373 & 545481 & 11.45 & 3 & Ferulic acid & 4.352 & 9.00055 & 7.84 \\
\hline 4 & Sinapic asid & 5.44 & 445366 & 9.35 & 4 & Sinapic acid & 5.423 & 6.20378 & 9.78 \\
\hline 5 & O-cumaric & 6.672 & 441940 & 9.28 & 5 & O-cumaric & 6.782 & 284530 & 12.26 \\
\hline 6 & Rutin & 7.60 & 584451 & 12.27 & 6 & Rutin & 7.568 & 168223 & 13.37 \\
\hline 7 & Myricetin & 8.597 & 566220 & 11.88 & 7 & Myricetin & 8.475 & 103305 & 15.27 \\
\hline 8 & Quercetion & 9.537 & 487263 & 10.23 & 8 & Quercetin & 9.425 & 438903 & 16.99 \\
\hline 9 & Kaempferol & 10.443 & 544223 & 11.42 & 9 & Kaempferol & 8.425 & 57964 & 12.16 \\
\hline
\end{tabular}

\section{Results}

\section{Chemical structure analysis}

The results of HPLC analysis are presented in Table 1 . The results showed that $P$. lanceolata leaf extract contained important flavonoid glycosides, especially rutin, myricetin quercetin, and kaempferol at concentrations of $13.37 \mu \mathrm{g}, 15.27 \mu \mathrm{g}, 16.99 \mu \mathrm{g}$, and $15.37 \mu \mathrm{g}$, respectively. The percentage of these compounds was higher than that of the standard. Thus, the activity of $P$. lanceolata leaf extract may be attributed to these bioactive compounds (Fig. 1).

\section{Cytotoxicity assay}

The $P$. lanceolata leaf extract showed the most potent cytotoxic effects against the triple-negative cancer cell line CAL51, with an IC50 value of $23.7 \mu \mathrm{g} / \mathrm{ml}$ (Fig. 2b). In contrast, the extract showed no noticeable cytotoxic effect against MCF7, AMJ13, and MDAMB cells, with extremely high IC50 values for these cells: $250 \mu \mathrm{g} / \mathrm{ml}$ for MDAMB cells, $674 \mu \mathrm{g} / \mathrm{mL}$ for MCF7 cells, and $7200 \mu \mathrm{g} / \mathrm{ml}$ for AMJ13 cells. For comparison, the IC50 value of the extract for normal embryonic fibroblast cells was $430 \mu \mathrm{g} / \mathrm{mL}$ (Fig. 2). The cells treated with the extract showed decreased cell number
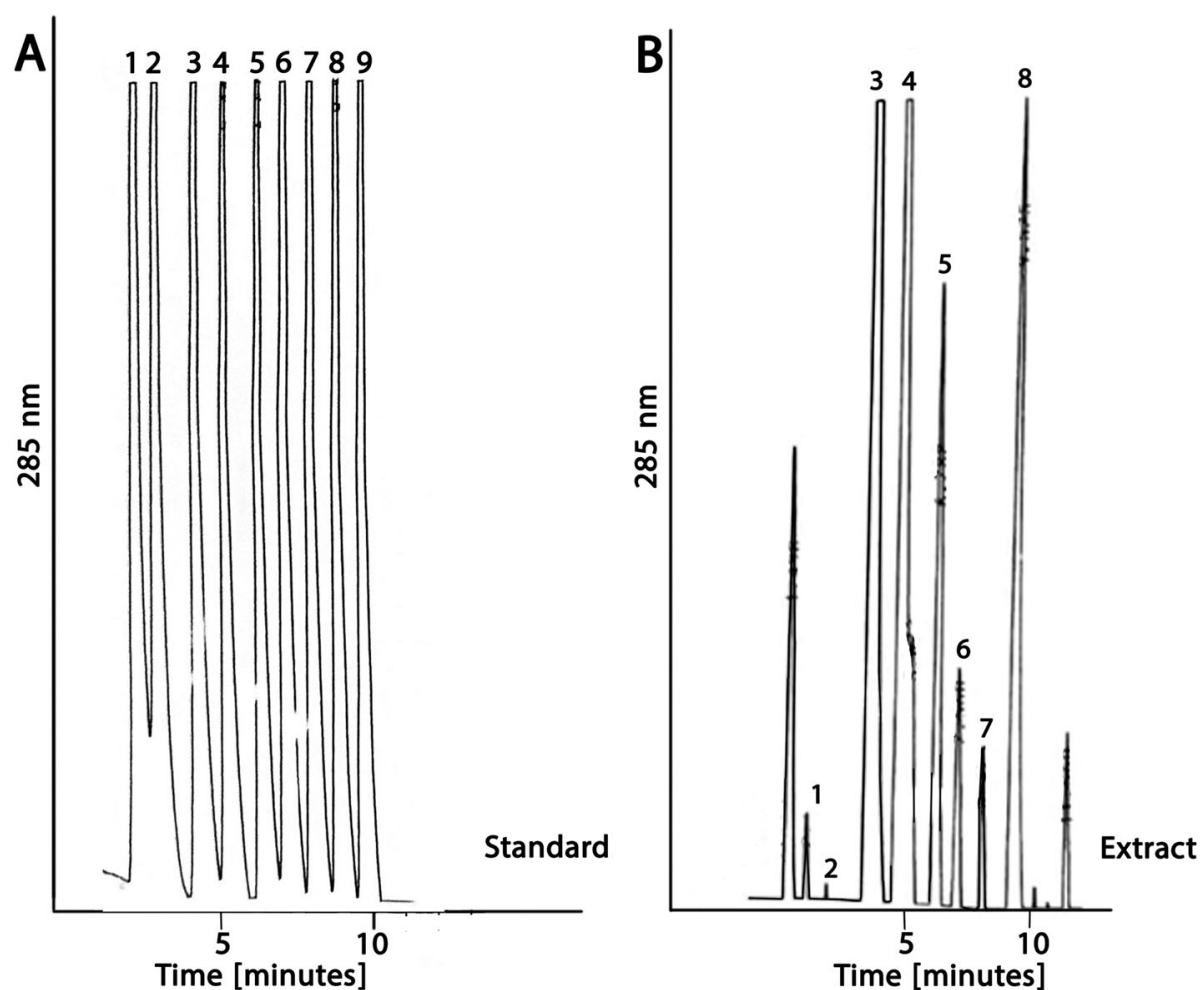

Fig. 1 HPLC chromatogram of P. lanceolata leaf extract. a HPLC trace standards. b P. lanceolata leaves ethanol extract monitored at $285 \mathrm{~nm}$. Peak identification: 1, protoctecuic acid; 2, cafeic acid; 3, ferulic acid; 4, sinapic acid; 5, O-cumaric; 6, rutin; 7, myricetin; 8, quercetin 

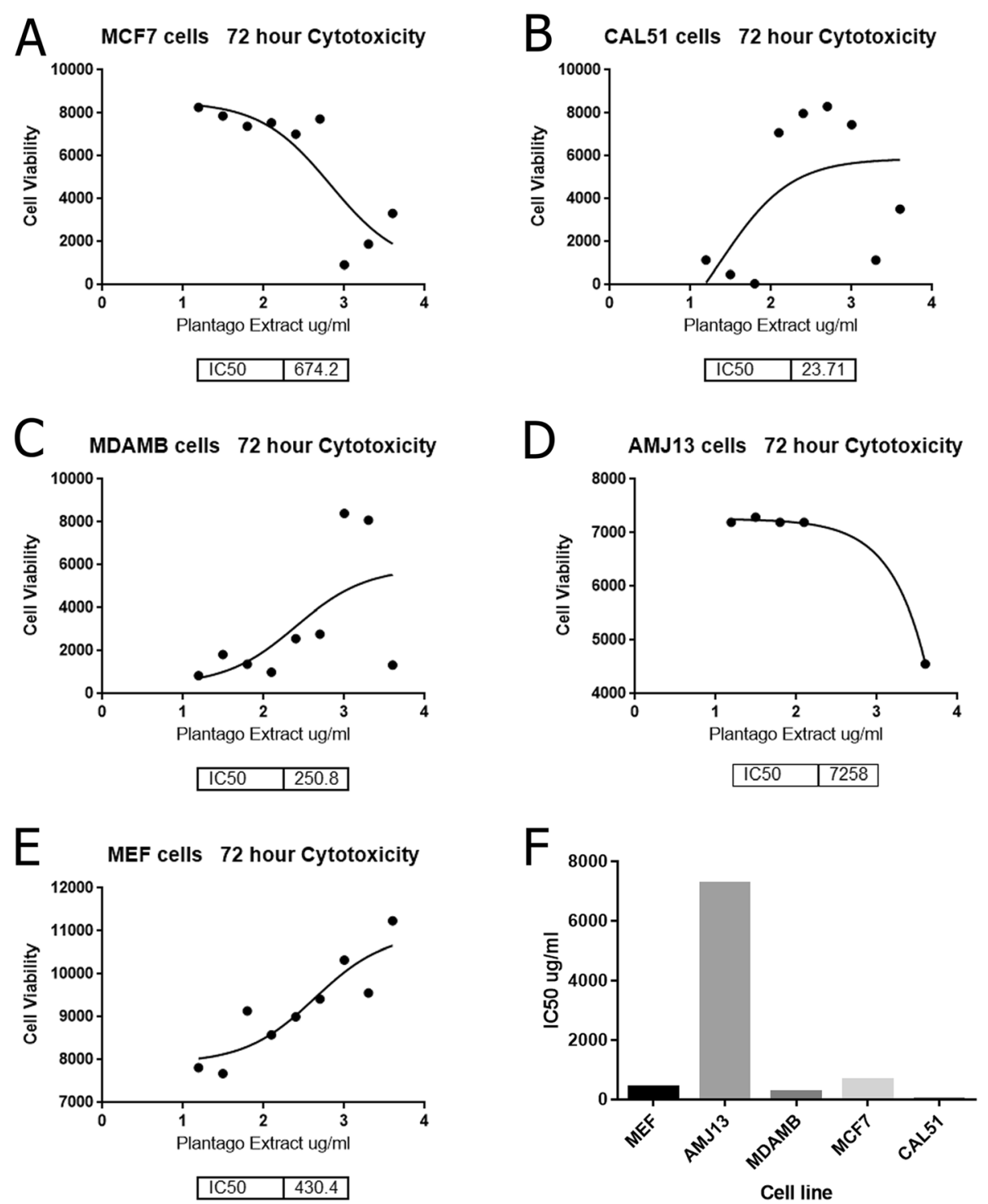

Fig. 2 The $P$. lanceolata leaf extract exhibited cytotoxicity against breast cancer cell lines, with different IC50 values of a $674.2 \mu \mathrm{g} / \mathrm{ml}$ for MCF7 cells, b $23.7 \mu \mathrm{g} / \mathrm{ml}$ for CAL51 cells, c $250.8 \mu \mathrm{g} / \mathrm{ml}$ for MDAMB cells, and $\mathbf{d} 7.2 \mathrm{mg} / \mathrm{ml}$ for AMJ13 cells, as well as against e normal embryonic fibroblast cells, with the IC50 value of $430 \mu \mathrm{g} / \mathrm{ml}$. f Comparative study of IC50 values showed that CAL51 cells were the most sensitive to the extract

owing to cell detachment, as observed in most of the observed fields. Furthermore, these cells showed condensed nuclei, indicating early apoptosis in the treated cells compared to untreated cells; this finding was observed in the cells treated with the highest concentration of extract. On the contrary, untreated cancer cells continued to proliferate to form monolayers. Early apoptotic cells with condensed nuclei and darker stain as well as lightly stained normal cells are shown in Fig. 3.

\section{Clonogenic assay}

More experiments were performed to assess the cytotoxic activity of $P$. lanceolata leaf extract at different concentrations against several breast cancer cell lines (MCF7, CAL51, MDAMB, and AMJ13 cells) and normal embryonic cells (MEF cells) using clonogenic assay. The efficacy of the extracts in inhibiting colony formation of the tested cells was determined. $P$. lanceolata leaf extract at a high concentration of $4 \mathrm{mg} / \mathrm{mL}$ showed high efficacy in inhibiting colony formation of CAL51 cells but showed low efficacy in inhibiting that of the other breast cancer cells. The extract at the same concentration showed less effect on other breast cancer cells and on normal MEF colony forming when we used the same concentration (Fig. 4). These findings suggested that $P$. lanceolata leaf extract selectively suppressed the proliferation of CAL51 triple-negative breast cancer cells. 

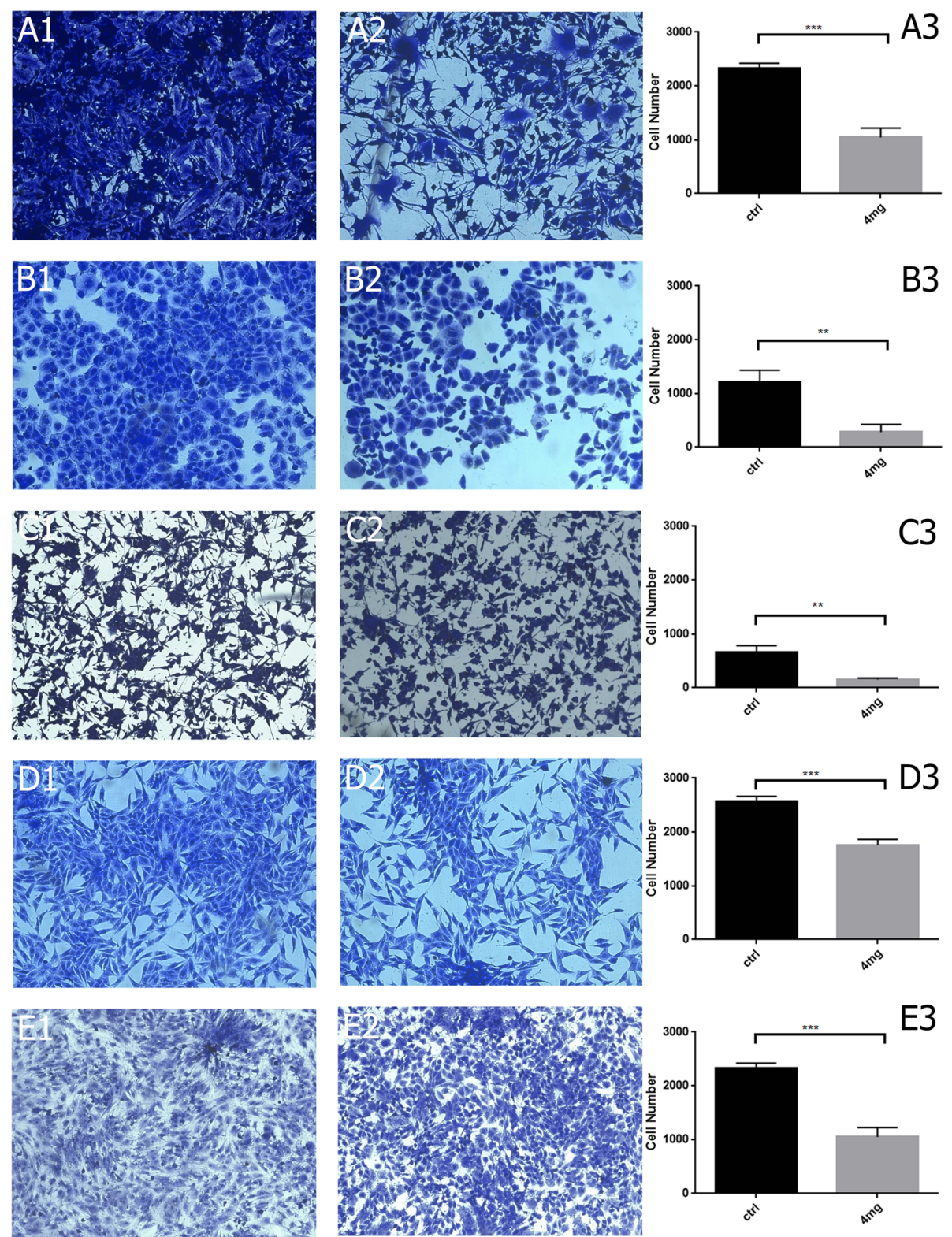

Fig. 3 Cytomorphology and quantitative image analysis of the treated and control cells. a MCF-7 cells: A1, control cells; A2, treated cells; A3, graph showing the efficacy of high-dose extract. b CAL51 cells: B1, control; B2, treated; B3, graph the efficacy of high-dose extract. c MDAMB cells: C1, control cells; C2, treated cells; C3, graph showing the efficacy of high-dose extract. d AMJ13 cells: D1, control; D2, treated extract; D3, graph showing the efficacy of high-dose extract. e MEF cells: E1, control cells; E2, treated cells; E3, graph showing that high-dose extract was cytotoxic to normal cells; $\times 400$ magnification; crystal violet staining

\section{Discussion}

The search of natural sources for cancer therapeutics has brought promising results thus far. Active compounds have been identified and isolated for use in cancer therapy. Several species of Plantago have been described as remedies for treating tumors [24]. In this study, flavonoids were identified by HPLC as major constituents of $P$. lanceolata leaf extract. Flavonoids are a group of compounds with different phenolic structures and known for their health benefits. There are over 4000 types of flavonoids; several of them are responsible for the color of fruits, flowers, and leaves [25]. The oxygen-derived free radical-scavenging activity of flavonoids has been shown to lead to anticarcinogenic effects [26]. Antioxidative effect is the defining feature of nearly every group of flavonoids. Flavones and catechins are flavonoids with the ability to protect the body from reactive oxygen species-induced damage. Cellular organelles and components can be damaged by reactive oxygen species and other free radicals, which are generated as a result of exogenous stimuli or oxygen metabolism 


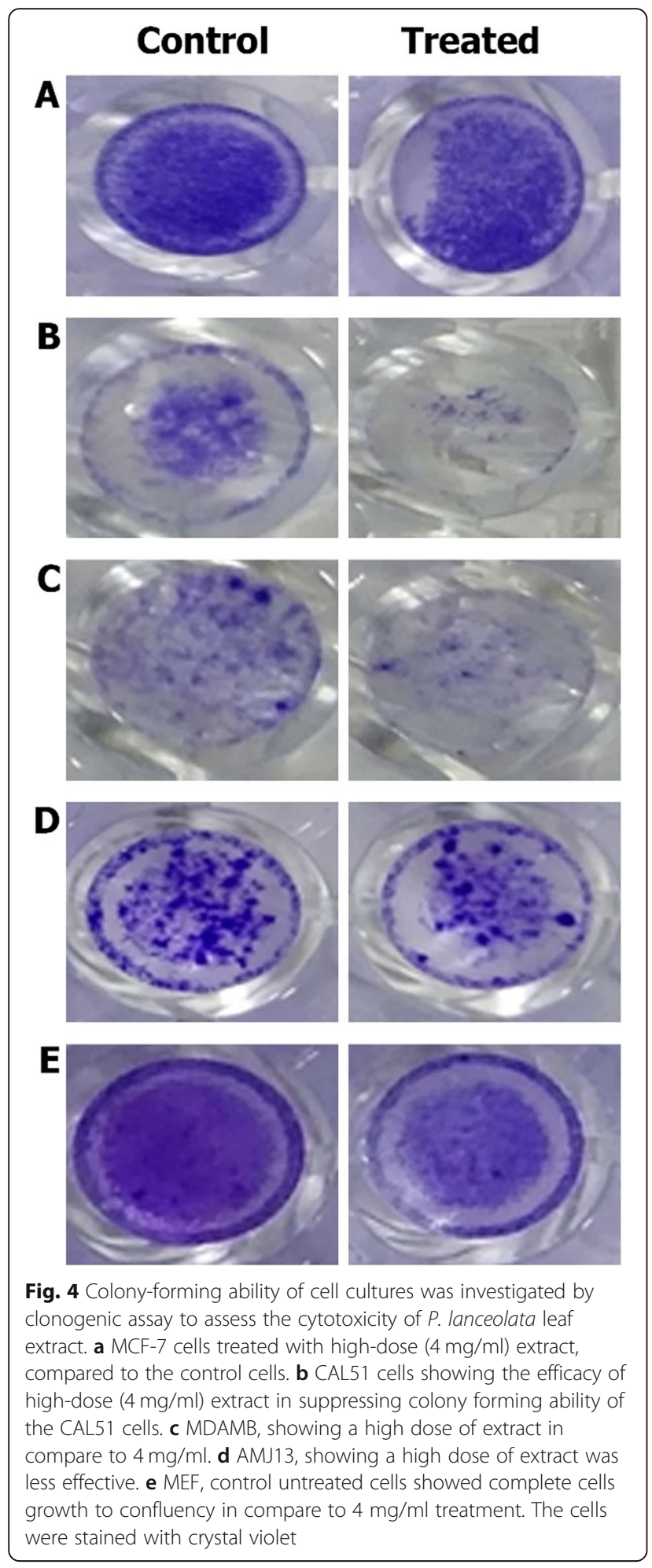

[27]. Increased production of reactive oxygen species leads to consumption and exhaustion of endogenous free radical-scavenging compounds. Flavonoids may exert additive effect on these endogenous free radicalscavenging compounds [28].
The results of cytotoxicity and clonogenic assays in the present study revealed that $P$. lanceolata leaf extract exhibited antiproliferative effect and cytotoxicity against breast carcinoma cell lines, especially CAL51 triplenegative breast cancer cells. The cytotoxic effect of the extract may be attributed to its flavonoid content, namely flavone and luteolin-7-O- $\beta$-glucoside [29]. Luteolin-7-O$\beta$-glucoside is a promising anticancer molecule with antibreast adenocarcinoma activity [24]. Another team [30] found that $P$. lanceolata extract is effective against MCF7 cell line and the IC50 value is $142.78 \mu \mathrm{g} / \mathrm{ml}$ while our study found that IC50 on MCF7 cells is $674.2 \mu \mathrm{g} / \mathrm{ml}$ and the difference may attributed to the difference in extraction method, but it still higher than required for CAL51 breast cancer cells. The IC50 value on prostate cancer cell lines PC-3 and Du-145 was about $300 \mu \mathrm{g} / \mathrm{ml}$ [18]. These results are the same range of our results but not for the AMJ13 which was very resistant, while CAL51 was very sensitive as IC50 value was $23.71 \mu \mathrm{g} / \mathrm{ml}$.

\section{Conclusions}

This study reported, for the first time, that P. lanceolata leaf extract exerted selective antiproliferative effect against CAL51 triple-negative breast cancer cells. Thus, this extract was potential for development as an anticancer agent for triple-negative breast cancer patients.

\section{Abbreviations \\ FBS: Fetal bovine serum; HPLC: High-performance liquid chromatography; IC50: Inhibitory concentrations 50\%; MEF: Mouse embryo fibroblasts}

\section{Acknowledgements}

The authors thank the staff of Experimental Therapy Department, Iraqi Center for Cancer and Medical Genetic Research, Mustansiriyah University, for their help and support during the work and for providing the cell lines.

\section{Authors' contributions}

AMA and MHM carried out the cytotoxicity sssay studies. ISA and KMA participated in the HPLC analysis and preparation of the extract. AMA, MHM, KMA, and ISA drafted the manuscript. AMA and MHM carried out the morphological study. AMA, MHM, KMA, and ISA participated in the design of the study and performed the statistical analysis, conceived of the study, and participated in its design and coordination and helped to draft the manuscript. All authors read and approved the final manuscript.

\section{Funding}

Not applicable.

\section{Availability of data and materials}

The datasets used and/or analyzed during the current study are available from the corresponding author on reasonable request.

\section{Ethics approval and consent to participate}

The Scientific committee of Iraqi Center for Cancer and Medical Genetic Research, Mustansiriyah University, approved the study (reference number:531) as well as the Pharmacy Department, Al-Esraa University College: Baghdad, Iraq (reference number: 3731 ).

\section{Consent for publication}

Not applicable.

\section{Competing interests}

The authors declare that they have no competing interests. 


\section{Author details}

${ }^{1}$ Pharmacy Department, Al-Esraa University College, Baghdad, Iraq. 'Experimental Therapy Department, Iraqi Center for Cancer and Medical Genetic Research, Mustansiriyah University, Baghdad, Iraq. ${ }^{3}$ Department of Pharmacognosy and Medicinal Plants, College of Pharmacy, Mustansiriyah University, Baghdad, Iraq.

Received: 4 September 2019 Accepted: 27 November 2019

Published online: 30 December 2019

\section{References}

1. O'Connor CM, Adams JU, Fairman J. Essentials of cell biology, vol. 1. Cambridge, MA: NPG Education; 2010.

2. Al-Shammari AM. Environmental pollutions associated to conflicts in Iraq and related health problems. Rev Environ Health. 2016;31(2):245-50.

3. (Iraq) MoH. Iraq Cancer Registry 2015. Baghdad, Iraq: Ministry of Health (Iraq); 2015.

4. Alsabah AS, Abd AH, Al-Shammari AM. Cytotoxicity of Xanthium strumarium against breast cancer cell lines. J Global Pharma Technol. 2018;10(3):767-76.

5. Sahoo N, Manchikanti P, Dey SH. Herbal drug patenting in India: IP potential. J Ethnobiol Ethnomed. 2011;137(1):289-97.

6. Ahmed HM. Ethnopharmacobotanical study on the medicinal plants used by herbalists in Sulaymaniyah Province, Kurdistan, Iraq. J Ethnobiol Ethnomed. 2016:12:8.

7. Grigore A, Bubueanu C, Pirvu L, lonita L, Toba G. Plantago lanceolata L. Crops-source of valuable raw material for various industrial applications. Scientific Papers-Series A, Agronomy. 2015;58:207-14.

8. Jacke D, Toensmeier E. Edible Forest Gardens, Volume I: ecological design and practice for temperate-climate permaculture: Chelsea Green Publishing; 2005.

9. Hasan AK, Ibrahim SA, Amani AT, Monther FM. Determination, isolation, and identification of aucubin and verbascoside in the leaves of Iraqi Plantago lancoleta L. using different detecting methodS. Int J Pharm Pharm Sci. 2018;11(2)

10. Maksyutina N. Hydroxycinnamic acids of Plantago major and PI. lanceolata. Chem Nat Compd. 1971;7(6):795.

11. Andary C, Motte-Florac M, Gargadennec A, Wylde R, Heitz A. Les esters caféiques du genre Plantago. Identification et valeur chimiotaxinomique. PI Med Phytotherap. 1988;22(1):17-22.

12. Murai M, Tamayama $Y$, Nishibe S. Phenylethanoids in the herb of Plantago lanceolata and inhibitory effect on arachidonic acid-induced mouse ear edema 1. Planta Med. 1995;61(05):479-80.

13. Handjieva N, Saadi H, Evstatieva L. Iridoid Glueosides from Plantago altissima L., Plantago lanceolata L., Plantago atrata Hoppe and Plantago argentea Chaix. Zeitschrift für Naturforschung C. 1991;46(9-10):963-5.

14. Wichtl M. Herbal drugs and phytopharmaceuticals: a handbook for practice on a scientific basis: Medpharm GmbH Scientific Publishers; 2004.

15. Fons F, Rapior S, Gargadennec A, Andary C, Bessière J-M. Volatile components of Plantago lanceolata (Plantaginaceae). Acta Bot Gallica. 1998; 145(4):265-9.

16. Núñez Guillén ME, da Silva Emim JA, Souccar C, Lapa AJ. Analgesic and antiinflammatory activities of the aqueous extract of Plantago major L. Int J Pharmacogn. 1997;35(2):99-104.

17. Daştan SD, Daştan T, Cetinkaya S, Ateşşahin D, Karan T. Evaluation of in vitro anticancer effect of Plantago major L. and Plantago lanceolata L. leaf extracts from Sivas. Cumhuriyet Üniversitesi Sağlık Bilimleri Enstitüsü Dergisi. 2016;1(1):7-14

18. Asadi-Samani M, Rafieian-Kopaei M, Lorigooini Z, Shirzad H. A screening of growth inhibitory activity of Iranian medicinal plants on prostate cancer cell lines. BioMedicine. 2018;8(2):8.

19. Kashams A, Hamza MA, Abbas IS. Effect of humic and salicylic acids on oil yield and flavonoid glycoside of safflowers (Carthamus tinctorius L.) as medicinal plants grown in Iraq. Int J Pharm Sci Res. 2018;9(5):2100-4.

20. Al-Shammari AM, Alshami MA, Umran MA, Almukhtar AA, Yaseen NY, Raad $K$, et al. Establishment and characterization of a receptor-negative, hormone-nonresponsive breast cancer cell line from an Iraqi patient. Breast Cancer: Targets Ther. 2015;7:223-30.

21. Al-Shammari AM, Salman MI, Saihood YD, Yaseen NY, Raed K, Shaker HK, et al. In vitro synergistic enhancement of Newcastle Disease Virus to 5fluorouracil cytotoxicity against tumor cells. Biomedicines. 2016;4(1):3.
22. Al-Shammari AM, Syhood Y, Al-Khafaji AS. Use of low-power He-Ne laser therapy to accelerate regeneration processes of injured sciatic nerve in rabbit. Egypt J Neurol Psychiatr Neurosurg. 2019;55(1):1.

23. Jabir MS, Taha AA, Sahib UI, Taqi ZJ, AI-Shammari AM, Salman AS. Novel of nano delivery system for Linalool loaded on gold nanoparticles conjugated with CALNN peptide for application in drug uptake and induction of cell death on breast cancer cell line. Mater Sci Eng C. 2019;94:949-64.

24. Gálvez M. Martı, X, n-Cordero C, López-Lázaro M, Cortés F, et al. Cytotoxic effect of Plantago spp. on cancer cell lines. J Ethnopharmacol. 2003;88(2):125-30.

25. de Groot $H$, Rauen $U$. Tissue injury by reactive oxygen species and the protective effects of flavonoids. Fundam Clin Pharmacol. 1998;12(3):249-55.

26. Panche AN, Diwan AD, Chandra SR. Flavonoids: an overview. J Nutr Sci. 2016:5:e47-e.

27. Jung W, Chung I, Kim S, Kim M, Ahmad A, Praveen N. In vitro antioxidant activity, total phenolics and flavonoids from celery (Apium graveolens) leaves. J Med Plant Res. 2011;5(32):7022-30.

28. Garcia-Orozco KD, Sanchez-Paz A, Aispuro-Hernandez E, Gomez-Jimenez S, Lopez-Zavala A, Araujo-Bernal S, et al. Gene expression and protein levels of thioredoxin in the gills from the whiteleg shrimp (Litopenaeus vannamei) infected with two different viruses: The WSSV or IHHNV. Fish Shellfish Immunol. 2012;32(6):1141-7.

29. Pettit GR, Hoard MS, Doubek DL, Schmidt JM, Pettit RK, Tackett LP, et al. Antineoplastic agents 338. The cancer cell growth inhibitory. Constituents of Terminalia arjuna (Combretaceae). J Ethnopharmacol. 1996;53(2):57-63.

30. Beara IN, Lesjak MM, Orčić DZ, Simin NĐ, Četojević-Simin DD, Božin BN, et al. Comparative analysis of phenolic profile, antioxidant, antiinflammatory and cytotoxic activity of two closely-related Plantain species: Plantago altissima L. and Plantago lanceolata L. LWT - Food Science and Technology. 2012;47(1):64-70.

\section{Publisher's Note}

Springer Nature remains neutral with regard to jurisdictional claims in published maps and institutional affiliations.

\section{Submit your manuscript to a SpringerOpen ${ }^{\bullet}$ journal and benefit from:}

- Convenient online submission

- Rigorous peer review

- Open access: articles freely available online

- High visibility within the field

- Retaining the copyright to your article

Submit your next manuscript at $>$ springeropen.com 